\title{
POR MOVIMENTOS SOCIAIS - REFLEXÕES À LUZ DOS PRINCÍPIOS DE DIREITO PENAL MÍNIMO
}

Adahilton Dourado Júnior*

Resumo: O artigo analisa a pretensão da criminalização primária das ocupações de propriedades públicas e privadas por movimentos sociais, tendo como marco teórico o pensamento de Alessandro Baratta sobre os limites de intervenção penal estatal, especialmente os princípios da "proporcionalidade abstrata" e da "articulação autônoma dos conflitos e das necessidades reais".

Palavras-chave: Conflito. Terra. Crime. Dignidade.

Abstract: The article examines the claim of primary criminalization of occupations of public and private properties by social movements having as theoretical thinking of Alessandro Baratta on the limits of state penal intervention, especially the principles of "abstract proportionality" and of "autonomous articulation of conflicts and real needs".

Keywords: Conflict. Land. Crime. Dignity.

\section{Introdução}

O presente artigo tem por objetivo analisar a juridicidade e a constitucionalidade da criminalização de ocupações de propriedades públicas e privadas por movimentos sociais tal qual pretendem fazer proposições legislativas em trâmite no Congresso Nacional. Com uso de método que poderia ser entendido como exegético-hermenêutico, por meio da leitura da Constituição Federal, e com apoio, em especial, da doutrina de Alessandro Baratta, buscar-se-á demonstrar como iniciativas dessa natureza ofendem o que pode ser considerado o principal fundamento de nosso Estado Democrático de Direito: a dignidade da pessoa humana.

A escolha de Alessandro Baratta para o atingimento desse objetivo reside no fato de esse autor deslocar o enfoque teórico geralmente dado ao "criminoso" pelo paradigma etiológico para as condições objetivas, estruturais e funcionais presentes na origem do ato de delinquir, superando esse paradigma e suas implicações ideológicas para inserir a questão na

\footnotetext{
* Adahilton Dourado Júnior, advogado da União requisitado para a Câmara dos Deputados desde 2007.

Mestrando em Filosofia pela Unb.
} 
perspectiva da criminologia crítica. A opção por sua doutrina, enquanto marco teórico das reflexões que ora se propõe, significa, pois, entender o crime não como uma realidade ontológica, mas como um status que o Sistema de Justiça como um todo atribui a determinadas pessoas em face de uma seleção de bens que se pretendem politicamente protegidos.

A escolha, por outro lado, da propriedade como bem jurídico tutelado para ser objeto da análise pretendida justifica-se pelas possibilidades de reflexão que promove sob diversas perspectivas. No caso, propicia análise sob o ponto de vista do proprietário, mas também e em especial da de quem luta pelo pleno acesso a ela, e, ao mesmo tempo, da do Estado enquanto ente garantidor desses direitos quando concorrem e se antagonizam entre si. Justifica-se a escolha, outrossim, em virtude de assim proceder, criando-se, noutra medida, a oportunidade de colocar em discussão um dos principais programas constitucionais instituídos por nossa Carta Magna de 1988, tendo em mira a dignidade humana: a Reforma Agrária.

Tantos são os conflitos de terras no Brasil, que foi instaurada, em 2003, pelo Congresso Nacional, uma Comissão Parlamentar Mista de Inquérito, a chamada "CPMI da Terra"1. Marcada por forte divisão ideológica entre seus membros, esta Comissão teve como Relator o Deputado Federal João Alfredo, do PSOL. O Relatório Final produzido por ele apresentava como solução da violência no campo, em apoio aos movimentos sociais, a efetiva reforma agrária. Contudo, suas conclusões foram rejeitadas, tendo sido referido documento substituído por um relatório do Deputado Federal Abelardo Lupion (do então PFL-PR) na votação em plenário.

Da leitura do relatório aprovado e da discussão da matéria no âmbito do funcionamento da CPMI, vê-se que a bancada parlamentar vencedora, de modo equivocado, conforme se pretende demonstrar, sugeriu a tipificação criminal da conduta atinente às ocupações coletivas, de propriedades públicas devolutas e privadas improdutivas por movimentos sociais. Alinhando-se, em certa medida, ao que entende o Supremo Tribunal Federal ${ }^{2}$, de que o fato das ocupações pode configurar esbulho possessório criminoso, em contraposição ao entendimento do Superior Tribunal de Justiça no julgamento do Habeas Corpus $n^{\circ} 5.574 / \mathrm{SP}$ que, em favor de um dos líderes do Movimento dos Sem Terra, José Rainha, concluiu pela atipicidade da conduta ${ }^{3}$.

\footnotetext{
${ }^{1}$ Criada para realizar amplo diagnóstico sobre a estrutura fundiária brasileira, os processos de reforma agrária e urbana, os movimentos sociais de trabalhadores, assim como os movimentos de proprietários de terras.

2 (...) constitui atividade à margem da lei, sem qualquer vinculação ao sistema jurídico, a conduta daqueles que, particulares, movimentos ou organizações sociais, visam, pelo emprego arbitrário da força e pela ocupação ilícita de prédios públicos e de imóveis rurais, a constranger, de modo autoritário, o poder público a promover ações expropriatórias, para efeito de execução do programa de reforma agrária. (...) O esbulho possessório, além de qualificar-se como ilícito civil, também pode configurar situação revestida de tipicidade penal, caracterizando-se, desse modo, como ato criminoso (CP, art. 161, § 1º, II; Lei $n^{\circ} 4.947 / 66$, art. 20) (ADI 2.213-MC, Rel. Min. Celso de Mello, DJ 23/04/04).

${ }^{3}$ Voto do Ministro Luiz Vicente Cernicchiaro, no Habeas Corpus $n^{\circ}$ 5.574/SP: “... No amplo arco dos Direitos de Cidadania, situa-se o direito de reivindicar a realização dos princípios e normas constitucionais. A Carta Política não é mero conjunto de intenções. De um lado, expressa o perfil político da sociedade, de outro gera direitos. É, pois, direito reclamar a implantação da reforma agrária. Legítima a pressão aos órgãos competentes para que aconteça,
} 
Consta do Anexo do Voto em Separado do Deputado Federal Abelardo Lupion ${ }^{4}$, projeto de lei para alterar o art. 161 do Decreto-Lei $n^{\circ} 2.848$, de 7 de dezembro de 1940 , e o art. $1^{\circ}$ da Lei $\mathrm{n}^{\circ} 8.072$, de 25 de julho de 1990, a fim de prever o esbulho possessório com fins políticos e enquadrá-lo no rol dos crimes hediondos, verbis:

Art. $1^{\circ} \mathrm{O}$ art. 161 do Decreto-Lei $\mathrm{n}^{\circ} 2.848$, de 7 de dezembro de 1940, passa a viger com o seguinte $\S 2^{\circ}$, renumerando-se os atuais $\S \S 2^{\circ}$ e $3^{\circ}$ para, respectivamente, $\S \S 3^{\circ}$ e $4^{\circ}$ :

"Art. 161.

$\S 1^{\circ}$

\section{Esbulho possessório com fins políticos}

$\S 2^{\circ}$ Saquear, invadir, depredar ou incendiar propriedade alheia, ou manter quem nela se encontra em cárcere privado, com o fim de manifestar inconformismo político ou de pressionar o governo a fazer ou deixar de fazer alguma coisa:

Pena - reclusão, de três a dez anos.

Art. $2^{\circ} \mathrm{O}$ art. 92 do Decreto-Lei n ${ }^{\circ} 2.848$, de 7 de dezembro de 1940, passa a viger acrescido do seguinte inciso:

"Art. 92

IV - a extinção de pessoa jurídica legalmente instituída e utilizada para prática de crime por iniciativa ou consentimento de seus dirigentes.

(NR)"

Art. $3^{\circ} \mathrm{O}$ art. $1^{\circ}$ da Lei $\mathrm{n}^{\circ} 8.072$, de 25 de julho de 1990, passa a viger acrescido do seguinte inciso:

"Art.1".

VII-C - esbulho possessório com fins políticos (art. 161, §2º $)$.

(NR)"

Do mesmo relatório consta outra proposta legislativa para acrescentar parágrafo ao art.

20 da Lei $\mathrm{n}^{\mathrm{0}} 7.170$, de 14 de dezembro de 1983, com o propósito de prever a conduta de quem invade propriedade alheia com o fim de pressionar o governo como ato terrorista, in verbis:

Art. $1^{\circ} \mathrm{O}$ art. 20 da Lei $\mathrm{n}^{\circ} 7.170$, de 14 de dezembro de 1983, passa a viger acrescido do seguinte parágrafo:

"Art. 20.

$\S 1^{\circ}$

$\S 2^{\circ}$ Incide nas mesmas penas quem saqueia, invade, depreda ou incendeia propriedade alheia, ou mantém quem nela se encontra em cárcere privado, com o fim de manifestar inconformismo político ou de pressionar o governo a fazer ou deixar de fazer alguma coisa. (NR)"

manifeste-se historicamente. Reivindicar, por reivindicar, insista-se, é direito. O Estado não pode impedi-lo. O modus faciendi, sem dúvida, também é relevante. Urge, contudo, não olvidar o princípio da proporcionalidade - tão ao gosto dos doutrinadores alemães. A postulação da reforma agrária, manifestei, em Habeas Corpus anterior, não pode ser confundida, identificada com o esbulho possessório, ou a alteração de limites. Não se volta para insurpar a propriedade alheia. A finalidade é outra. Ajusta-se ao Direito. Sabido, dispensa prova, por notório, o Estado há anos, vem remetendo a implantação da reforma agrária. Os conflitos resultantes, evidente, precisam ser dimensionados na devida expressão. Insista-se. Não se está diante de crimes contra o Patrimônio. Indispensável a sensibilidade do magistrado para não colocar, no mesmo diapasão, situações jurídicas distintas. ... Tenho o entendimento, e esse Tribunal já o proclamou, não é de confundir-se ataque ao direito do patrimônio com o direito de reclamar a eficácia e efetivação de direitos, cujo programa está colocado na Constituição. Isso não é crime; é expressão do direito de cidadania".

${ }^{4}$ Relatório Final da Comissão Parlamentar Mista de Inquérito da Reforma Agrária e Urbana - CPMI da Terra. Anexo "Propostas Legislativas".Voto em Separado do Deputado Federal Abelardo Lupion. Brasília, Congresso Nacional, 2005, p. 382. 
A primeira proposta legislativa tramita desde o dia 18 de setembro de 2006 como Projeto de Lei do Senado sob o $\mathrm{n}^{\circ} 264^{5}$; a segunda, desde o dia 20 do mesmo mês, como Projeto de Lei $n^{\circ} 7.485$, na Câmara dos Deputados ${ }^{6}$. O primeiro, após grande resistência a uma regular tramitação, foi arquivado no dia 11 de janeiro de 2011, com base no art. 332 do Regimento Interno do Senado (final de legislatura). O segundo se encontra pronto para a pauta do Plenário da Câmara, na $54^{\mathrm{a}}$ Legislatura.

O fato das ocupações, a sua repercussão no âmbito do Poder Legislativo e as suas interpretações judiciais, fácil ver, demonstram incertezas quanto à matéria. Os operadores do Direito vacilam perante o conflito de direitos fundamentais, entre a garantia da propriedade ${ }^{7}$ e a garantia do direito de acesso a ela por grandes contingentes populacionais ${ }^{8}$ em busca da concretização da dignidade da pessoa humana ${ }^{9}$. Há divisão social quanto à reprovabilidade da

\footnotetext{
${ }^{5}$ Vide Justificação in Voto em separado - Relato dos trabalhos da "CPMI da Terra”, p. 382: "As ações perpetradas pelo Movimento dos Trabalhadores Sem Terra (MST) são inaceitáveis perante o nosso ordenamento constitucional, e vem gozando da falta de tipicidade de seus atos. O Judiciário não vem aceitando ações penais do Ministério Público contra o MST com base no crime de esbulho possessório, previsto no art. 161, § $1^{\circ}$, II, do Código Penal, uma vez que o referido tipo penal pede por um elemento subjetivo específico (dolo específico), que é o animus de esbulhar. O MST tem, com êxito, defendido que o fim de seus atos não é o esbulho possessório em si, mas manifestar inconformismo político e pressionar o governo a executar políticas sociais. Assim, suas condutas restariam atípicas. O presente projeto vem para corrigir essa lacuna legal, e dar ao nosso direito penal força para punir essa ação que afronta os princípios constitucionais da propriedade, da livre iniciativa, da liberdade e até mesmo da função social da propriedade, visto que muitas das terras invadidas pelo Movimento são produtivas. Trata-se, em suma, de afronta ao regime representativo e democrático e ao Estado de Direito, o que desvela a natureza hedionda desse crime, de efeitos sociais muito mais graves do que várias das condutas previstas no rol da Lei nº 8.072, de 1990. A alteração no art. 92 do Código Penal é não menos importante, pois possibilita, como efeito da condenação em sentença motivada, a extinção de pessoa jurídica legalmente instituída usada por seus dirigentes para a prática de crime, em tributo aos valores sociais do trabalho e da livre iniciativa, erigidos como fundamento de nosso Estado democrático de direito (art. $1^{\circ}$, IV, da Constituição Federal). Com este projeto tornado lei, buscamos dar resposta eficaz ao estágio que chegou esse tipo de movimento dito "social", que impõe inaceitável desrespeito à liberdade social e à autoridade do Estado e fragiliza o processo jurídico-democrático, o qual, há vinte anos, vem se consolidando em nosso País".

${ }^{6}$ Vide Justificação in Voto em separado - Relato dos trabalhos da "CPMI da Terra", p. 385: "O terrorismo é um dos crimes mais multifacetados da História contemporânea. Apresenta-se na forma de fundamentalismo religioso no Oriente Médio; sob a forma de insurreicionismo étnico nos Bálcãs; sob a forma de independentismo nacional na Espanha etc. O terrorismo, que é eminentemente um movimento político, adapta-se à realidade social, econômica e cultural do local onde se exterioriza. No Brasil, tem se manifestado na forma do inclusionismo socioeconômico (...). Com este projeto tornado lei, buscamos dar resposta eficaz ao estágio a que chegou esse tipo de terrorismo, que impõe inaceitável desrespeito à liberdade social e à autoridade do Estado e fragilização do processo jurídicodemocrático, o qual, há vinte anos, vem se consolidando em nosso País."

7 "Não é lícito ao Estado aceitar, passivamente, a imposição, por qualquer entidade ou movimento social organizado, de uma agenda político-social, quando caracterizada por práticas ilegítimas de invasão de propriedades rurais, em desafio inaceitável à integridade e à autoridade da ordem jurídica. O Supremo Tribunal Federal não pode validar comportamentos ilícitos. Não deve chancelar, jurisdicionalmente, agressões inconstitucionais ao direito de propriedade e à posse de terceiros. Não pode considerar, nem deve reconhecer, por isso mesmo, invasões ilegais da propriedade alheia ou atos de esbulho possessório como instrumentos de legitimação da expropriação estatal de bens particulares, cuja submissão, a qualquer programa de reforma agrária, supõe, para regularmente efetivar-se, o estrito cumprimento das formas e dos requisitos previstos nas leis e na Constituição da República. As prescrições constantes da MP 2.027-38/2000, reeditada, pela última vez, como MP $\mathrm{n}^{\circ} 2.183-56 / 2001$, precisamente porque têm por finalidade neutralizar abusos e atos de violação possessória, praticados contra proprietários de imóveis rurais, não se mostram eivadas de inconstitucionalidade (ao menos em juízo de estrita delibação), pois visam, em última análise, a resguardar a integridade de valores protegidos pela própria Constituição da República. O sistema constitucional não tolera a prática de atos, que, concretizadores de invasões fundiárias, culminam por gerar - considerada a própria ilicitude dessa conduta - grave situação de insegurança jurídica, de intranqüilidade social e de instabilidade da ordem pública." (cf. ADI 2.213-MC, Rel. Min. Celso de Mello, DJ 23/04/04)

${ }^{8}$ Levantamento feito pela Ouvidoria Agrária Nacional indica que existem atualmente 72 entidades e ou movimentos sociais envolvidos nos conflitos agrários ou em ocupações de terras no Brasil.

9 "Enquanto campear a incerteza de seus resultados e for incerta a atuação política, encontrar-se-á a revolta justa e a insatisfação crescente dos menos favorecidos nos contextos econômico, social e político do Brasil'". (STJ; HC 050220; Ministro Paulo Medina; DJ 02/12/2005).
} 
conduta dos integrantes dos movimentos sociais que ocupam terras e não há, como visto, consenso quanto à sua tipicidade penal ou sobre a necessidade de sua tipificação.

Não há dúvida, no entanto, de que a soberania popular legitima os movimentos sociais a transformar o Estado de direito brasileiro meramente formal em um "Estado dos Direitos Humanos" e de que é preciso encontrar a interpretação jurídica que melhor atenda à função de pacificação exercida pelo Direito, uma vez que esses movimentos provocam tensão social com mortes nos confrontos entre proprietários "invadidos" e "ocupantes sem terras".

Passados dez anos da instauração da CPMI da Terra, tendo como marco teórico o pensamento de Alessandro Baratta sobre os limites de intervenção penal estatal, especialmente os princípios da "proporcionalidade abstrata" e "da articulação autônoma dos conflitos e das necessidades reais", analisar-se-á a pretensão da criminalização primária das ocupações de propriedades públicas e privadas por movimentos sociais.

Para este efeito, entende-se 'movimentos sociais' como a sociedade civil organizada na assunção de ações de caráter político na esfera pública, tendo por base a solidariedade, os direitos humanos fundamentais e a soberania popular, para estabelecer novas formas de relação com o Estado brasileiro.

\section{A ilegitimidade da criminalização frente ao direito fundamental à dignidade}

Sendo o conceito penal de esbulho possessório mais restrito do que o civil, para que haja crime é necessário que a invasão, praticada em terreno ou imóvel alheio, com violência à pessoa ou grave ameaça, ou, ainda, em concurso de pessoas, tenha por fim o esbulho. Inexistirá o elemento subjetivo exigido pelo tipo previsto no art. 161, $§ 1^{\circ}$, II, do Código Penal, se a conduta ocorrer no âmbito de movimentos sociais clamando por reforma agrária ${ }^{10}$, porque, neste caso, não haverá a intenção do agente de tomar a propriedade alheia, apropriando-se da terra. "Nesses termos, não há que se confundir a turbação e o esbulho da posse, previstos no CC (...) com o crime de esbulho possessório aqui tratado, que exige o referido elemento subjetivo" (DELMANTO, 2003, p. 370).

Isso posto, a discussão que se trava é sobre ser possível a tipificação das ocupações como 'esbulho possessório com fins políticos', hipótese não prevista no regime jurídico vigente, e cujo dolo específico é o de "esbulhar" com o fim de manifestar inconformismo político ou de pressionar o governo a fazer ou deixar de fazer alguma coisa, tal qual sugeriram os parlamentares integrantes da CPMI da Terra.

O crime não é ontológico (HULSMAN, 1997, p. 64), mas construção cultural da sociedade que visa regular determinadas condutas (NEPOMOCENO, 2004, p.55). Há uma

\footnotetext{
${ }^{10}$ Se o movimento popular visa a pressionar o governo para acelerar a implementação da reforma agrária, programa constante da CR, não se está diante de movimento para tomar a propriedade alheia, não havendo que se falar, portanto, no crime contra o patrimônio previsto no art. 161, §1 $1^{\circ}$, II (STJ, $m v-R T 747 / 608$; TJSP, RT 787/594).
} 
seletividade intrínseca no sistema de controle penal que a tem como lógica de funcionamento, que começa com a criminalização da conduta na lei (criminalização primária) e se realiza operativamente na aplicação pelo juiz (criminalização secundária).

Tratando-se a hipótese que a CPMI da Terra pretende ver criminalizada, de conduta coletiva reivindicatória de um direito devido e não prestado pelo Estado, é de perquirir-se da legitimidade de este mesmo Estado, devedor da prestação, criminalizar o reclamo dela por movimentos sociais, em face tanto da omissão estatal quanto do princípio da dignidade da pessoa humana ultrajado por esta omissão, selecionando como 'criminosos' uma classe de pessoas excluída do processo de divisão da riqueza nacional.

Vale refletir sobre os fundamentos da decisão do STF antes citada acerca "da necessária observância dos princípios e diretrizes que estruturam o ordenamento positivo nacional"11. É que, mormente na seara penal, resta evidente a existência de um código ideológico, "além da lei” (NEPOMOCENO, 2004, p. 228), a balizar o funcionamento do Sistema de Justiça Criminal, desde o inquérito até a sentença, de modo a selecionar uns, criminalizando-os, e excluindo outros $^{12}$.

A questão deve, então, ser analisada levando em conta um sistema não só jurídico, mas também político, econômico e social. A dogmática no Direito Penal e o paradigma etiológico na Criminologia se distanciaram da realidade. Entraram na modernidade em estado de crise e assim permanecem na pós-modernidade, com objetivos ambíguos de regulação e emancipação, prometendo, para salvar-se, de um lado, o controle do crime, garantida a segurança à sociedade e, de outro, sua emancipação, com o desenvolvimento de processos tendentes às realizações dos direitos humanos, sem, no entanto, cumprir tais promessas ${ }^{13}$.

A lógica do sistema decorre da ideia de que a conduta social indigitada como ofensiva a essa sociedade pode ser evitada se estiver prevista na lei como crime. Daí a disseminação de tipos penais que traduzem a cultura social e política do Estado, aprofundando a crise. Dentro desta perspectiva, o Eficientismo domina a contemporaneidade como forma de ajuste do sistema. De outro lado, surgem versões sociais de política criminal que sugerem como solução para controle da criminalidade o combate à pobreza e à exclusão social, numa tentativa de suplantação daqueles que justificam a repressão penal na necessidade de combater a criminalidade em reação oficial à delinquência entendida como 'desvios' causados por fatores biológicos, psicológicos ou sociais.

\footnotetext{
${ }^{11}$ Vide ADI 2.213-MC, Rel. Min. Celso de Mello, DJ 23/04/04.

${ }^{12}$ Consta do depoimento de Dom Tomás Balduíno, constante do relatório do Voto Vencido do Deputado Federal João Alfredo, na votação do Relatório Final da Comissão Parlamentar Mista de Inquérito da Reforma Agrária e Urbana - CPMI da Terra. Brasília, Congresso Nacional, 2005, que de 1985 a 2004, foram vítimas de homicídio 1349 lavradores, em 1003 ocorrências diferentes, em conflitos agrários no interior do Brasil. Apenas 75 dessas ocorrências teriam sido julgadas, tendo sido 64 executores condenados e 44 absolvidos. Só 15 mandantes foram condenados, ao passo que 6 foram absolvidos.

${ }^{13}$ Anotações de aula da disciplina "Sistema de Justiça Criminal" ministrada por Vera Regina Pereira de Andrade, no Curso de Especialização em Sistema de Justiça Criminal. Convênio FESMPDFT e Universidade Federal de Santa Catarina, 2005.
} 
A ruptura paradigmática, no entanto, se impõe, para reconhecer que, na realidade, o sistema atribui, injustamente, a certas pessoas (de certas classes, sexo e cor), a responsabilidade pelos conflitos sociais. O início de uma nova postura parte do admitir que o que se faz hoje, num primeiro momento é decidir, politicamente, quais condutas serão consideradas crimes em um processo formal de criminalização primária, na lei; e depois, a seleção de quem será atingido por ela, em atendimento às 'crenças' e 'etiquetagens' do sistema, na criminalização secundária, por meio do inquérito policial, da formulação da denúncia pelo Ministério Público e do seu julgamento pelo Judiciário.

A política de contenção da violência punitiva, ao largo de tudo isso, deve refletir a afirmação dos direitos humanos para que seja uma política penal realista (BARATTA, 2003, p. 4), na medida em que não se pode isolar a violência concebida como violência institucional da violência estrutural e da injustiça das relações de propriedade e de poder. "A sociedade brasileira se caracteriza por disparidades sociais vertiginosas e por pobreza de massa que, ao se combinarem, alimentam o crescimento inexorável da violência criminal" (WACQUANT, 2001, p. 7) à qual corresponde o crescimento de uma repressão policial absolutamente ineficaz, na medida em que não tem influência alguma sobre os motores dessa 'criminalidade'(Idem).

O sistema punitivo, ao abarcar esta hipótese de crime, será então mais um incremento do suporte à violência estrutural da instituição social, em prol da repressão das necessidades reais da maior parte dos cidadãos brasileiros. Nesta realidade, a busca pela concretização da promessa do sistema de realizar os direitos humanos passa a ser fundamental para o encontro da solução das questões atinentes a esta violência (estrutural).

A eficácia vertical dos direitos fundamentais invocada pelos movimentos sociais enfatiza a relação homem-Estado para cobrar ação governamental. Mas há também, e o regime jurídico pátrio a reconhece, mormente sob a égide de sua opção capitalista, eficácia horizontal a ser considerada na relação privada que se estabelece homem-homem, da qual se extrai não só direitos, mas os deveres respectivos deles decorrentes. É necessário, pois, a priori, considerar a diferença existente entre as ocupações que se operam em propriedades públicas daquelas que se operam em propriedade privadas:

se parece hoje inquestionável a necessidade de extensão dos direitos
fundamentais à arena das relações privadas, muito mais polêmica é a forma e
intensidade desta incidência. Neste particular, é oportuno recordar que,
diversamente do Estado, que tem de ser juridicamente limitado, o indivíduo é
essencialmente livre, e a sua autonomia, numa ordem democrática, constitui
direito fundamental constitucionalmente protegido. Não seria aceitável
sujeitar o cidadão ao mesmo regime vigente para o Estado, na qualidade de
sujeito passivo dos direitos fundamentais, diante da liberdade
constitucionalmente desfrutada pelo primeiro, que se apresenta como
corolário inafastável da sua dignidade como pessoa humana, em oposição ao
caráter intrinsicamente limitado do segundo. É importante não esquecer que,
como pontuou Robert Alexy, "(...) la relación Estado / ciudadano es una
relación entre um titular de derecho fundamental y un no titular de derecho 
fundamental. Em cambio, la relación ciudadano/ ciudadano es una relación entre titulares de derechos fundamentales. "(SARMENTO, 2006a, p. xxvii).

Em razão disso é que se vislumbra, em contrapartida do direito fundamental à dignidade invocado pelos movimentos sociais, a eficácia do direito de propriedade, também fundamental, como um aspecto a ser considerado como força indicativa de ação estatal interventiva penal, para considerar a hipótese em questão como crime, como já o fez o $\mathrm{STF}^{14}$, ou para considerar a necessidade da criminalização primária da conduta, como pretende o parlamento brasileiro ${ }^{15}$, em proteção ao patrimônio.

Sob o ângulo da eficácia plena que possuem os direitos fundamentais reconhecidos pela Constituição, trata-se de conduta atípica e impossível, juridicamente, de ser tipificada. A eficácia dos direitos fundamentais na hipótese de "ocupação" de imóvel rural particular, na relação do indivíduo em face de outro indivíduo, tendo em vista que é o proprietário quem sofre diretamente os efeitos da "cobrança" do movimento social, opera-se não só verticalmente, mas também horizontalmente. Isso porque os direitos fundamentais, que são históricos, universais, inalienáveis e imprescritíveis, são também relativos, e, assim sendo, sempre haverá conflito a ser dirimido pelo Estado de Direito, atinente aos direitos dos "ocupantes" em relação aos direitos dos "invadidos", mas nunca, neste caso, sob a égide da intervenção estatal penal ${ }^{16}$.

De plano, pode-se, com referida distinção, demonstrar baixa ou nenhuma reprovabilidade social e jurídica da conduta consistente na ocupação de terras públicas devolutas. O proprietário, neste caso o Estado, será o próprio devedor da prestação requerida e devida, ex vi legis. Suscitado, o Estado deve reagir, mas administrativamente, com reforma agrária tão-somente. ${ }^{17}$. Se a moderna dogmática dos direitos fundamentais os tem discutido à luz da possibilidade de o Estado-Administração vir a ser obrigado a criar os pressupostos fáticos necessários ao exercício efetivo dos direitos constitucionalmente assegurados, considerando a titularidade de direito de pretensão a prestações estatais, essas prestações deverão ser, outrossim, exercitáveis em face do proprietário (privado) quando lhes autorizarem o interesse social de que trata o art. 184 da Constituição, por se tratar, outrossim, de questão de interesse geral, na medida em que sua atuação - quando negligente e enquanto não cumprida a função social de sua propriedade - afeta negativamente toda a sociedade.

Numa sociedade que tem o pluralismo como fundamento (art. $1^{\circ}, \mathrm{CF}$ ), é preciso engajamento geral em causas comuns e cooperação solidária alicerçados na "percepção de cada

\footnotetext{
${ }^{14}$ Vide Nota $\mathrm{n}^{\mathrm{o}} 2$

${ }^{15}$ Vide Notas nos 5 e 6.

16 O direito fundamental da propriedade do "invadido", mitigado em face da dignidade da pessoa humana e do interesse social que a questão suscita, restará protegido, civil e administrativamente, pelo direito que lhe cabe à indenização justa por sua propriedade desapropriada, observado o devido processo legal.

${ }^{17}$ No caso das ocupações de terras privadas, no entanto, é preciso maiores reflexões acerca dos seus desdobramentos que devem estar adstritos à seara civil, processual e administrativa. Acerca disso, vide monografia do autor Contradições Lógico-Formais do Capitulo III - "Da Política Agrícola e Fundiária e da Reforma Agrária" - do Título VII - "Da Ordem Econômica e Financeira - da Constituição Federal Brasileira. Proposta de um novo conceito de propriedade produtiva”. Brasília: IDP - Instituto Brasiliense de Direto Público, 2003. Não publicado.
} 
pessoa que vive sob a égide de um regime constitucional que trata todos com o mesmo respeito e consideração; na compreensão de que cada indivíduo não é súdito do Estado, mas cidadão partícipe da formação da vontade coletiva, mas também titular de uma esfera de direitos invioláveis; sujeito e não objeto da História." (SARMENTO, 2006a, p. 319). Por outro lado,

\begin{abstract}
es absolutamente inadmisible afirmar, como resulta de ciertas exposiciones y aun de algunas decisiones jurisprudenciales, que la Administración disponga de um poder general implícito o derivado de la cláusula general del orden público (...) para poder condicionar, limitar o intervir los derechos y libertades constitucionalmente proclamados em orden a uma hipotética articulación de los mismos com la utilidad común o general. Esta es uma tesis rigorosamente procedente del absolutismo (...) pero totalmente incompatible con la construción moderna del Estado de Derecho. (ENTERRÍA e FERNANDEZ apud SARMENTO, 2006a, p. 302).
\end{abstract}

Os movimentos sociais, quando das ocupações de terras públicas ou privadas improdutivas, estarão exercendo o legítimo direito de reclamar reforma agrária e dignidade enquanto obrigação exigível do Estado e não cumprida por ele, sob a égide da eficácia vertical (em face do Estado) e horizontal relativa (em face do proprietário privado) do direito fundamental à dignidade da pessoa humana invocado na sua função de prestação e de defesa para, respectivamente, exigir ação governamental (reforma agrária) e proibir o Estado de agir (legiferar ilegitimamente normas de criminalização primária de seus reclamos sociais).

Se a luta pela contenção da violência estrutural é a mesma luta pela afirmação dos direitos humanos, há de se reconhecer a ilegitimidade da medida legislativa. Com efeito, em uma concepção histórico-social, os direitos humanos assumem um conteúdo idêntico ao das necessidades reais historicamente determinadas (BARATTA, 2003, p. 4) que não podem ser contidas, não legitimamente, pela lei, mormente pela lei penal.

\title{
3 Afronta aos Princípios de Direito Penal Mínimo
}

A partir da ideia de uma intervenção estatal penal mínima, Alessandro Baratta articula princípios intrassistemáticos e extrassistemáticos relativamente ao Sistema de Justiça Criminal, para o que procura, programaticamente, estruturar uma política penal que prestigie os direitos humanos com uma primeira função negativa, ao impor limites à intervenção penal, e outra positiva, ao estabelecer um direito penal protetivo do que possa ser entendido, progressivamente, como direito humano (BARATTA, 2003, p. 4). Vislumbra-se, pois, a possibilidade de se colocar o princípio da dignidade da pessoa humana a serviço da função positiva referida, assumindo o direito de acesso à propriedade rural como direito dele decorrente. Exitosa esta medida, como parece ser em decorrência da interpretação constitucional invocada, impor-se-á o respeito ao princípio na primeira função, negativa, de impedir a intervenção legislativa penal. 
Na linha de que a hipótese que se trata é a de movimentos sociais entendidos como expressão da cidadania em reclamo à concretização da dignidade de cada cidadão, a criminalização das ocupações, no âmbito intrassistemático de Baratta, ofende diversos princípios jurídicos, v.g., o da idoneidade ${ }^{18}$, o da subsidiariedade ${ }^{19}$; o da adequação social $^{20}$; do respeito pelas autonomias culturais (BARATTA, 2003, p. 9); o da exigibilidade social ${ }^{21}$ e mais flagrantemente, o princípio da resposta não contingente, na medida em que, à luz deste fundamento jurídico, o critério geral é o da autonomia da resposta penal; essa, por regra, deve constituir o conteúdo principal do ato legislativo, e não, como amiúde ocorre, e que se repetiria no caso, representar somente uma linha secundária de reforço a respeito da disciplina jurídica de matérias não penais (BARATTA, 2003, p. 7).

Ofende, outrossim, o princípio da proporcionalidade abstrata ${ }^{22}$ porque o Direito Penal ao limitar as hipóteses de sanções penais somente às graves violações aos direitos humanos, denuncia o não cabimento da produção normativa à espécie, em exame da colisão dos valores em questão (SARMENTO, 2006b, pp. 267-324) - se verdadeiramente colisão houver no caso, na medida em que reforma agrária é questão de interesse público e não de certa classe - não pode o controle pretendido com a tipificação penal proteger (com proporcionalidade) o bem jurídico "propriedade rural" porque não pode fazê-lo em detrimento do direito à dignidade de ser humano garantido constitucionalmente a cada um do povo e também sem tolher o direito legítimo de reclamá-lo em face da omissão histórica do Estado. Não seria proporcional.

A utilização dos princípios da proporcionalidade ou da proibição de excesso, normas constitucionais não escritas, derivadas do Estado de Direito, envolve a apreciação da necessidade e adequação da providência legislativa. A doutrina identifica como típica manifestação do excesso de poder legislativo a violação ao princípio da proporcionalidade ou da proibição de excesso, de que tanto fala Gilmar Mendes, (Verhältnismässigkeitsprinzip; Übermassverbot), que se revela mediante contraditoriedade, incongruência, e irrazoabilidade ou inadequação entre meios e fins. A tipificação penal da conduta coletiva reivindicatória de cidadania concreta em questão, fácil ver, configura flagrante excesso legislativo (MENDES, 2006).

\footnotetext{
${ }^{18}$ Segundo Baratta, op. cit., p. 12, "Esse princípio obriga o legislador a realizar um atento estudo dos efeitos socialmente úteis que cabe esperar da pena".

${ }^{19}$ Para Baratta, op. cit. P. 12, aqui "Não basta (...) haver provado a idoneidade da resposta penal; requer-se, também, demonstrar que essa não é substituível por outros modos de intervenção de menor custo social".

${ }^{20}$ Neste caso, conforme Baratta, op. cit. p.13, “(...) deve-se considerar o fato de que a violência penal pode agravar e reproduzir os conflitos nas áreas específicas em que aquela intervém (...)”.

${ }^{21}$ Exigibilidade social, aqui, segundo Baratta, “(...) Em uma construção dogmática, baseada no contexto situacional da ação, mas que, em um 'elemento interior', tão dificilmente operacionável, como demonstra a experiência teórico prática, teriam que definir-se as seguintes séries de requisitos normativos: 1. Causas de não-exigibilidade social do comportamento, conforme a lei e os critérios para sua verificação em relação ao contexto situacional da ação e aos papéis sociais ou institucionais cobertos pelo sujeito na situação problemática. 2. Critérios de avaliação do espectro de alternativas comportamentais à disposição do sujeito na situação problemática em que levou a cabo a ação"(op. cit., p. 13).

${ }^{22}$ Para Baratta, op. cit., p. 9, este princípio significa que "somente graves violações aos direitos humanos podem ser objeto de sanções penais". Ou seja, "as penas devem ser proporcionais ao dano causado pela violação".
} 
Se os princípios fundamentais constituem o núcleo principal da Constituição a irradiar o seu conteúdo sobre ela como um todo, com carga eficacial de hierarquia superior em face do subsistema referenciado, e se, ainda, nessa ordem de ideias, a dignidade da pessoa humana é a que possui maior hierarquia, não há que duvidar que qualquer norma positiva que lhe for contrária, tanto ordinária quanto constitucional, será inevitavelmente ilegítima. De acordo com essa leitura principiológica, criminalizar o reclamo da dignidade dos excluídos do rol daqueles que já exercitam cidadania será ilegítimo e, repita-se, materialmente inconstitucional.

De modo mais preocupante ainda, a tipificação pretendida ofende um princípio metodológico da construção alternativa dos conflitos e dos problemas sociais arrolados como um dos mais importantes princípios extrassistemáticos da mínima intervenção de Alessandro Baratta, o chamado "princípio da articulação autônoma dos conflitos e das necessidades reais". De acordo com este princípio, "o Sistema Penal constitui um aspecto da expropriação ideológica que sofremos, sujeitos de necessidades e de direitos humanos, por parte do sistema e da cultura dominante, com referência à percepção dos conflitos em que se acham envolvidos." (BARATTA, 2003, p. 16)

Nenhuma mudança democrática na política do controle social pode ser realizada se os sujeitos de necessidades e direitos humanos não conseguem passar de sujeitos passivos de um tratamento institucional e burocrático a sujeitos ativos na definição dos conflitos de que formam parte e na construção das formas e dos instrumentos de intervenção institucional e comunitária idôneos para resolvê-los, segundo suas próprias necessidades reais.

A articulação autônoma da percepção e da consciência dos conflitos, das necessidades reais e dos direitos humanos, por parte de seus próprios portadores, em uma comunicação não condicionada pelo poder, e a idéia da democracia e da soberania popular são os princípios-guia para a transformação do Estado, não somente para um modelo formal de Estado de Direito, senão, também, para um modelo substancial do Estado dos direitos humanos (BARATTA, 2003, p. 17).

A criminalização pretendida, sob este ângulo de vista, deve ser veementemente rechaçada, na medida em que o tipo penal idealizado servirá apenas ao engessamento da realidade social do País na situação em que se encontra hoje, em favor de uma classe privilegiada pelo processo político-social desencadeado no Brasil desde a sua origem em detrimento de outra, alijada do processo democrático nacional de desfrute de cidadania, em ofensa ao modelo perseguido e baseado substancialmente na realização dos direitos humanos, não de apenas alguns, mas de todos ${ }^{23}$.

A desconcentração fundiária no Brasil emerge como o grande desafio a ser enfrentado pela sociedade brasileira, porque foi a imensa concentração de terras nas mãos de poucos e a

\footnotetext{
${ }^{23}$ As concentrações da propriedade da terra e da renda de um País são medidas por um índice estatístico denominado Índice de Gini, variando de zero $(0,00)$ a um $(1,00)$. Zero indica igualdade absoluta, ao passo que um significa concentração absoluta. $\mathrm{O}$ índice brasileiro para a concentração fundiária é de 0,843 , bastante próximo à concentração absoluta.
} 
adoção de um modelo tecnológico socialmente excludente na atividade agropecuária nacional que causou e causa a expulsão do campo de milhões de trabalhadores, e, consequentemente, consiste em importante motivo de diversos problemas sociais sentidos, não só no interior, mas também nas grandes cidades brasileiras. É a razão essencial da crescente violência no campo, advinda dessa concentração e da resistência dos trabalhadores, organizados ou não, na luta pela terra como forma de sobrevivência ou de cobrança por ação estatal mais justa.

Todas as estatísticas demonstram que o Brasil possui um dos índices mais altos do mundo em concentração da propriedade da terra. Em consequência, o campo brasileiro padece de uma imensa desigualdade no acesso ao trabalho e à renda ${ }^{24}$. À concentração fundiária somase a improdutividade de grande parte das grandes propriedades rurais brasileiras. Dados oficiais do INCRA informam que $51,40 \%$ dos imóveis classificados como grande propriedade são improdutivos. Significa que mais de 133 milhões de hectares de terras não atendem às exigências mínimas de produtividade, os quais poderiam ser desapropriados ${ }^{25}$ para fins de reforma agrária.

Ademais, o estudo das várias reformas agrárias realizadas no mundo aponta para a constatação de que as várias reformas agrárias ocorridas no século XX promoveram considerável desenvolvimento social, como as reformas agrárias revolucionárias russa, chinesa, cubana, vietnamita e de alguns países da Europa oriental; as impostas, ocorridas no leste asiático após o final da Segunda Guerra Mundial, no Japão, na Coréia do Sul e em Formosa; bem como as convencionais, dentro dos marcos legais existentes ou dos acordos entre as diversas forças sociais, como na Colômbia, Venezuela, Costa Rica e Panamá, na América Latina e, no plano mundial, na Indonésia, Filipinas, Índia, Malásia, África do Sul, Marrocos e na Itália (SPAROVEK, 2003, pp. 8 e 9).

O Brasil não fez, ainda, a reforma agrária que deve fazer. Assim, sem grande esforço exegético, é possível extrair da realidade campesina brasileira e de todo o sistema jurídico vigente, que está fundado na dignidade da pessoa humana, a ideia de que cada indivíduo possui o direito de exercer plenamente a sua condição de cidadão (ANDRADE, 2003, pp. 138 e 139) e que, para isso, o Estado the deve reforma agrária e, mais minimamente ainda e pelo menos, o respeito ao direito de reclamá-la. Extrai-se de todo este arcabouço fático e jurídico, vale dizer, que os movimentos sociais exercem, na linha das ideias que defende Alessandro Baratta, a articulação autônoma da consciência das necessidades reais da classe trabalhadora rural brasileira e dos seus direitos humanos negligenciados pelo Estado, para pô-la em ação positiva e

\footnotetext{
${ }^{24}$ Sobre o assunto, vide depoimento de Plínio de Arruda Sampaio, em audiência na CPMI in Voto Vencido do Dep. João Alfredo.

${ }^{25}$ De acordo com monografia não publicada do autor - Contradições Lógico-Formais do Capitulo III - "Da Política Agrícola e Fundiária e da Reforma Agrária" - do Título VII - "Da Ordem Econômica e Financeira - da Constituição Federal Brasileira. Proposta de um novo conceito de propriedade produtiva", é preciso aferir o interesse social nas desapropriações para fins de reforma agrária com base, especialmente, nos princípios da proporcionalidade, razoabilidade, legalidade e economicidade, o que gera critérios de relativização da susceptibilidade da grandes propriedades rurais a esta sanção para efeito de maximização econômico-social da reforma agrária brasileira.
} 
propositiva, em forma de um exigir fundado na ideia de democracia e de soberania popular que os guie em direção às transformações que pretendem ver implementadas.

Este exigir com base nos fatos, nos direitos fundamentais não concretizados, nos princípios do ordenamento jurídico, tem apoio também no direito positivo, porque, nessa seara, nossa Carta de 1988 surgiu comandando o dever de legislar normas integrativas ${ }^{26}-v . g$. por meio dos arts. 184 e 187, normas constitucionais de princípio institutivo impositiva, atinentemente aos esquemas gerais de estruturação e atribuições de órgãos e entidades ou institutos (SILVA, 2003, p. 126) - normas estas já elaboradas e vigentes, não tendo porque o Estado brasileiro não proceder à reestruturação fundiária do País, salvo naquilo que estiver condicionado à reserva do financeiramente possível ("Vorbehalt des finanziell Möglichen"), no escólio de Gilmar Mendes.

Trata-se, para assim concluir, de uma apropriação lógico-sistemática decorrente "dos próprios potenciais simbólicos da Constituição" (ANDRADE, 2003, p. 139) e da principiologia do Estado democrático de direito brasileiro, a fim de permitir a cobrança de ação governamental para a efetivação de direito previsto na Lei Fundamental não cumprido pelo Estado Administração brasileiro, sem se pensar em crime, porque terminantemente proibido pelo regime jurídico constitucional vigente.

\section{Conclusão}

Relativizado o direito de propriedade em prol de toda a coletividade, dentro desta perspectiva da eficácia plena da dignidade da pessoa humana que está na base de todo o sistema jurídico a legitimá-lo como tal, será possível extrair dele a ideia de cidadão ("sem terra") no sentido de destinatário da proteção que o Estado opera em face desse direito fundamental considerado em suas funções (a) de prestação, de obrigação de fazer reforma agrária; (b) de promoção da igualdade material, na proteção das minorias para assegurar o pluralismo e a tolerância; (c) de proteção do indivíduo perante terceiros, na relação do homem e seu semelhante; mas, especialmente, (d) na função de defesa, quando impõe abstenção ao Estado, em defesa do indivíduo, de ativar a sua função legislativa intervencionista penal.

Nesta ordem de ideias, sintetiza-se, pois, as seguintes conclusões desta análise:

a) a reforma agrária é uma necessidade real da sociedade brasileira, e o regime jurídico constitucional brasileiro obriga o governo federal a realizá-la;

\footnotetext{
${ }^{26}$ Por imposição lógica das expressões "compete à União desapropriar" e "A Política Agrícola planejada e executada na forma da lei", presentes, respectivamente, no caput dos referidos dispositivos - bem como limitando e traçando princípios a serem cumpridos pelos órgãos legislativos, executivos, jurisdicionais e administrativos, como programas das respectivas atividades - normas programáticas dos arts. 184, 186 e 187, relativamente aos programas que estatuem - recepcionando legislação pré-existente (Estatuto da Terra), o que já supria as normas referidas, tanto no sentido institutivo, como no sentido programático.
} 
b) a atipicidade das ocupações baseia-se na circunstância de que a Constituição da República dedica o Capítulo III, do Título VII, à Política Agrícola e Fundiária e à Reforma Agrária, restando, assim, configurada a obrigação de o Estado fazê-la, efetivamente, havendo, com isso, correspondentemente à dita obrigação, direito público subjetivo de exigência e concretização;

c) a hipótese que se pretende tipificada não é passível de tipificação. Tratar-se-ia de norma materialmente inconstitucional, na medida em que a criminalização primária das ocupações ofende vários princípios constitucionais, mormente os da soberania popular, da proporcionalidade abstrata e o da dignidade da pessoa humana, que sustenta todo o arcabouço jurídico brasileiro;

d) a eficácia plena dos direitos humanos envolvidos e proporcionalmente considerados, denuncia a inconstitucionalidade material da iniciativa legislativa e os princípios que informam o Direito Penal Mínimo, sua injuridicidade;

e) a relação entre o Estado e o cidadão compreende uma relação de um não titular de direito fundamental (o Estado) com um titular de direito fundamental (o cidadão); a relação entre particulares envolve titulares de direitos fundamentais (os integrantes dos movimentos sociais e os proprietários invadidos);

f) as ocupações de propriedades públicas geram uma relação linear entre Estado e cidadão, cuja força eficacial plena do direito fundamental à dignidade da pessoa humana se dirige contra o Estado. Nesse caso, tratando-se de demanda por ação independente do próprio devedor, a reprovabilidade da ocupação é mínima;

g) as ocupações de propriedades privadas geram relação triangular que envolve direitos e deveres sujeitos a regras de direito público, mas, essencialmente de direito privado, cuja força eficacial se dirige em vetores de mão dupla, contra o Estado e contra os agentes envolvidos reciprocamente considerados nessa relação, mas a solução jurídica do conflito exclui as normas de Direito Penal;

h) o direito fundamental da propriedade tem peso menor que o da dignidade, na medida em que é direito dependente de conformação normativa, ao contrário da dignidade da pessoa humana que integra os princípios fundamentais da própria ordem constitucional que balizam todas as demais disposições constitucionais;

i) a dignidade da pessoa humana, como princípio ético de caráter hierarquicamente superior às normas constitucionais, é vinculativo do poder constituinte e, como tal, impede toda e qualquer regra positiva que lhe contrarie;

j) irradiando-se a eficácia da dignidade da pessoa humana por todo o ordenamento infraconstitucional como princípio dele informativo, não pode a lei ordinária criminalizar o que a própria Constituição invoca para efeito da concretização da cidadania brasileira; 
k) a tipificação pretendida, à luz dos critérios principiológicos intrassistemáticos da lição de A. Baratta, ofende os princípios da idoneidade, da subsidiariedade, da adequação social, do respeito pelas autonomias culturais, da exigibilidade social, da resposta não contingente e o da proporcionalidade abstrata;

1) à luz dos critérios principiológicos extrassistemáticos do mesmo autor, a proposta ofende, de modo especial, o princípio da articulação autônoma dos conflitos e das necessidades reais, por subtrair dos movimentos sociais a possibilidade-garantia, protegida pela Carta Magna, de a soberania popular, por articulação autônoma ativa e propositiva, agindo como sujeito de suas necessidades e direitos humanos, promover mudança democrática na política do controle social, tendo em vista os fundamentos e objetivos da República Federativa brasileira.

\section{Referências}

ANDRADE, Vera Regina Pereira de. Sistema Penal Máximo x Cidadania Mínima. Códigos da violência na era da globalização. Porto Alegre: Livraria do Advogado Editora, 2003.

BRASIL. Constituição da República Federativa do Brasil. Brasília, Senado Federal, 2006.

BRASIL. Relatório Final da Comissão Parlamentar Mista de Inquérito da Reforma Agrária e Urbana - CPMI da Terra. Voto em Separado do Deputado Federal Abelardo Lupion. Brasília, Congresso Nacional, 2005.

BRASIL. Relatório Final da Comissão Parlamentar Mista de Inquérito da Reforma Agrária e Urbana - CPMI da Terra. Voto Vencido do Relator Deputado Federal João Alfredo. Brasília, Congresso Nacional, 2005.

SÃO PAULO (Estado). Superior Tribunal de Justiça. Habeas Corpus n ${ }^{\circ}$ 5.574. LexMl: Rede de Informação Legislativa e Jurídica. 18 ago. 1997. Disponível em: <http://www.lexml.gov.br/urn/urn:lex:br:superior.tribunal.justica;turma.6:acordao;hc:1997-0408;5574-168566>. Acesso em: 19 mar. 2013.

BARATTA, Alessandro. Princípios do Direito Penal Mínimo: Para uma Teoria dos Direitos Humanos como Objeto e Limite da Lei Penal. Tradução de Francisco Bissoli Filho. Florianópolis, Santa Catarina: Universidade Federal de Santa Catarina, 2003.

DELMANTO, Celso. Código Penal Comentado. São Paulo: Renovar, 2003.

HULSMAN, Louk; CELIS, Jaqueline Bernart de. Penas Perdidas. O Sistema Penal em Questão. Tradução de Maria Lúcia Karam. Niterói, RJ: Luam, 1997.

MENDES, Gilmar Ferreira. Os direitos fundamentais e seus múltiplos significados na ordem constitucional. Revista Diálogo Jurídico, Salvador, CAJ - Centro de Atualização Jurídica, n. ${ }^{\circ}$ 10, janeiro, 2002. Disponível em: http://direitopublico.com.br. Acesso em 16 de março de 2013.

NEPOMOCENO, Alessandro. Além da Lei - A face obscura da sentença penal. Rio de Janeiro: Revan, 2004.

SARMENTO, Daniel. Direitos Fundamentais e Relações Privadas. Rio de Janeiro: Lumen Juris, 2006a.

SARMENTO, Daniel; GALDINO, Flávio (Orgs.). Colisões entre Direitos Fundamentais e Interesses Públicos. In Direitos Fundamentais: Estudos em Homenagem ao Professor Ricardo Lobo Torres. Rio de Janeiro, São Paulo, Recife: Renovar, 2006b, pp. 267-324. 
SILVA, José Afonso da. Curso de Direito Constitucional Positivo. 22 ${ }^{a}$ ed. São Paulo: Malheiros, 2003.

SPAROVEK, Gerd. Reforma Agrária no mundo: conceito e algumas experiências. In: SPAROVEK, Gerd. (Org.). A qualidade dos assentamentos da reforma agrária brasileira. São Paulo: Páginas \& Letras, 2003.

WACQUANT, Loïc. As Prisões da Miséria. Rio de Janeiro: Jorge Zahar Editor, 2001.

Artigo recebido em: 19/05/2013

Artigo aceito para publicação em: 05/08/2013 